\title{
Green business opportunity of coffee ground waste through reverse logistics
}

\section{Indrianawati Usman* and Paundra Viveka Nanda}

Faculty of Economics and Business, Department of Management, Airlangga University, Surabaya 60286, Indonesia Email: Indrianawati-u@feb.unair.ac.id Email: paundra.viveka@gmail.com ${ }^{*}$ Corresponding author

\begin{abstract}
The aim of this research is to explore the possibility to utilise coffee grounds produced by coffee shops, using green concept and reverse logistics. Exploratory case study approach is considered as the method for this purpose. Data were collected by interviewing people who manage coffee shops and community of urban farmer in Surabaya. This research concludes that a coffee shop cannot recycle their own coffee grounds because the amount of coffee grounds of a coffee shop is not much and there is no time or no human resources to manage recycling. Third parties need to recycle coffee grounds into valuable and environmentally-friendly products (such as coffee ground fertiliser). The result of this study is a green business opportunity model of recycling process of coffee grounds produced by coffee shops in order to become fertiliser, which is eventually consumed by the urban farming community in Surabaya.
\end{abstract}

Keywords: coffee grounds waste; waste management; green business; business opportunity; reverse logistics; waste recycling.

Reference to this paper should be made as follows: Usman, I. and Nanda, P.V. (2017) 'Green business opportunity of coffee ground waste through reverse logistics', J. Global Business Advancement, Vol. 10, No. 6, pp.721-737.

Biographical notes: Indrianawati Usman is a Lecturer of Operations and Supply Chain Management. He received his Master Graduate from ITB (Bandung Institute of Technology) and a Doctoral from Airlangga University. His research interests are in strategic operations and lean supply chain management. His current position is Head of Doctoral Management Study Program at Airlangga University.

Paundra Viveka Nanda is alumny of Master of Management at Airlangga University. Currently he works on supply chain area in DHL Surabaya Indonesia.

This paper is a revised and expanded version of paper entitled 'Green business design of coffee waste through reverse logistic for urban farming' presented at AGBA-SMARTCIEC Conference, Surakarta, Indonesia, 26-28 November, 2016. 


\section{Introduction}

Coffee is one of the popular beverages, which is currently becoming a trend and part of urban lifestyle. Based on the data collected from the Association of Indonesian Coffee Exporters (AICE), it was noted that the consumption of coffee by Indonesians is increasing rapidly.

Table 1 shows that that coffee consumption of Indonesian people has increased every year. In East Java, especially Surabaya as a second biggest city of Indonesia, the number of cafés/coffee shops is growing by $10-15 \%$ annually alongside the acceleration of the infrastructure development in East Java. The acceleration of infrastructure in Surabaya which is also encouraged by the Surabaya city government will be a big potential for café entrepreneurs.

Figure 1 shows that the number of cafés/coffee shops located in the city of Surabaya which have processed coffee-based beverages for their core products (www. tripadvisor.com, 2016). This chart has been compiled based on data collected by Trip Advisor. The number of cafés/coffee shops in Surabaya, are four outlets in North Surabaya, 15 outlets in Central Surabaya, 20 outlets in West Surabaya, 18 outlets in East Surabaya, and 12 outlets in South Surabaya. The operation of coffee shop business covers several production and supply chain activities. The impact of coffee shop existence concerning with the environmental issue is waste from coffee making process, that is coffee ground. As known, the waste from the production process is the part of supply chain management that must be considered, especially in green supply chain management. Supply chain management is a set of activities in the form of entities or facilities involved in the process of transformation and distribution of goods ranging from raw materials from the very start to the final consumer. Implementation of supply chain management now has included the environmental factor which also considered as a global issue in a business.

Table 1 Data of coffee consumption in Indonesia

\begin{tabular}{lcccc}
\hline No. & Year & $\begin{array}{c}\text { Number of population } \\
\text { (persons) }\end{array}$ & Needs of coffee $(\mathrm{kg})$ & $\begin{array}{c}\text { Coffee consumption } \\
(\mathrm{kg} / \text { capita/year })\end{array}$ \\
\hline 1 & 2010 & $237,000,000$ & $190,000,000$ & 0.80 \\
2 & 2011 & $241,000,000$ & $210,000,000$ & 0.87 \\
3 & 2012 & $245,000,000$ & $230,000,000$ & 0.94 \\
4 & 2013 & $249,000,000$ & $250,000,000$ & 1.00 \\
5 & 2014 & $253,000,000$ & $260,000,000$ & 1.03 \\
6 & 2015 & $257,000,000$ & $280,000,000$ & 1.09 \\
7 & 2016 & $260,000,000$ & $300,000,000$ & 1.15 \\
\hline
\end{tabular}

Source: http://www.aeki-aice.org/uploads, 2016

The concept of green business/industry itself is known as the concept of green procurement (environmentally friendly procurement), green manufacturing, green distribution, and reverse logistics (Ninlawan et al., 2010). It is also in line with the concept of the triple bottom line, as quoted from the paper at www.swa.co.id in an edition of November 2010. The concept that defines sustainability and growth of the company depends not only on the profit alone, but also on the real action of the company to the 
social circumstances (people) and the environment (planet). The three components of the triple bottom line move dynamically depending on the circumstances and the pressure of social, political, economic, environmental, and due to possible conflicts of certain parties interest (Elkington, 1998). Besides, it also refers to the concept of the blue economy as stated by Pauli (2010), the concept of blue economy aims to provide opportunities for businesses to develop investment and business that brings more profit both economically and environmentally. Most of the previous research discussing the flow of forward logistics, which only concerns about the flow from suppliers to the final consumer. There is not much research that fundamentally studies about the flow in the backward or reverse performed from consumers, retailers, and to the company or from within the company itself. Theoretically, reverse logistics also has a major influence on the cost for both the companies and the suppliers (Daugherty et al., 2005).

Figure 1 Coffee shops in Surabaya (see online version for colours)

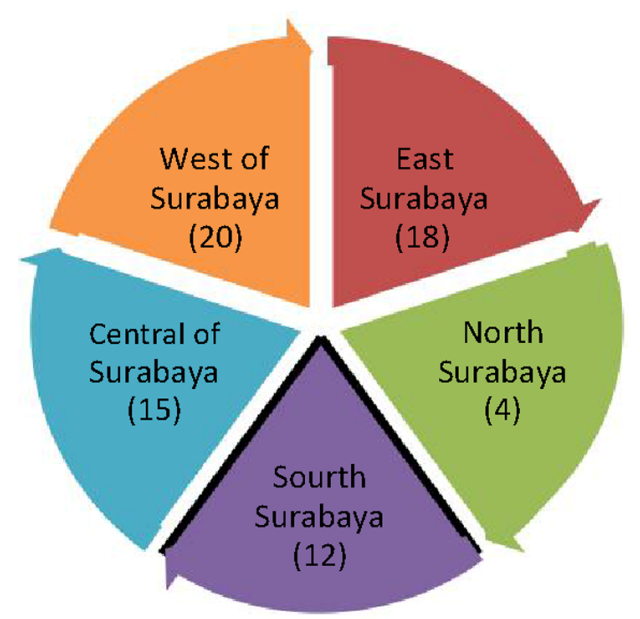

Source: www.tripadvisor.com, 2016

In line with the rapid growth of café/coffee shop business which is booming in Surabaya, then the waste from the café's business operations process such as coffee grounds is unavoidable. Reverse logistics contributes a solution to overcome this problem. Moreover, coupled with the green concept, not only increasing the value of coffee grounds, but also improving the quality of the environment surrounding. As noted in the paper at www.nationalgeographic.co.id in January 2015 edition, production of waste coffee grounds can be utilised into several new products such as hair care products, skin care, facial scrubs, and complementary ingredients kitchen, even briquettes, and manure or fertiliser. The research will focus on the use of coffee grounds that will be processed into fertiliser/fertiliser materials plants so that they will have economic values and also give a better impact on the environment. This research is intended to design green reverse logistics business through the management of waste. The results of this study are expected to provide benefits, such as for start-up businesses, to determine the design of green reverse logistics business through the waste management of coffee grounds in order to create economic value products and to provide a solution for the environment. 


\section{Theoretical background}

Lau and Wang (2009) discuss whether reverse logistics theory and model can be applied in developing countries using companies engaged in the electronic industry as a case study. It is mentioned that there are several value-added outcomes that can be obtained as a result of the implementation of reverse logistics, such as improve the company's advantages, reduce costs, and improve customer satisfaction. They use equation type for goods produced, including in the consumer goods category. Their research is similar to this research which aims to explore more about reverse logistics on waste management such as coffee grounds to create value added in supply chain process. Another study conducted by Muflichah (2014) entitled "Case Study of Application of Reverse Logistics Model in Cigarette Industry in Sidoarjo". The study discusses the application of reverse logistics that is conducted in the companies that become the object of research. One of the companies that became the object of research is Cigarette Company Rizky Putra Abadi, which has been doing reverse logistics management through waste management. The study also mentioned that the application of reverse logistics will provide value-added reduced costs that may be caused by the impact of product defects/product returns.

\subsection{Reverse logistics}

Reverse logistics is a process of planning, implementing, and controlling the efficiency and effectiveness of the flow of goods (raw materials, in-process inventories, or finished goods) and related information, from the consumer point back to the origin (Rogers and Tibben-Lembke, 1999). In this case, the handling of returned goods either salvage and scrap disposal, is part of a process that is closely related to reverse logistics, and is also a component of logistics that need more attention. Reverse logistics also involves the removal and disposal of waste material from the production, distribution and packaging. If the unnecessary waste material cannot be used to produce other products, the material must be removed. Figure 2 provides exposure to the key tasks in the flow and reverse logistics.

As stated by Jayaraman et al. (2003) reverse logistics is the flow in which the product or component coming back after being used for the purpose of repair, recycle or rework. In a world with limited resources and limited disposal facilities, recovery, or improvements made to the product or material is key to supporting the population with rising consumption levels (Georgiadis and Vlachos, 2004). The purpose of reverse logistics is to capture or re-create value or for disposal of goods flows back (Rogers and Tibben-Lembke, 1999). Currently, reverse logistics has a broader concept, as mentioned by Fleischmann et al. (1997). This activity seeks to renew the value of goods. Thus, not only of goods withdrawn from the market (distributors, retailers), but also from the enduser even bins a reverse logistics can be a solution to overcome this problem. Moreover, coupled with the green concept, not only will increase the value of coffee grounds, but also will improve the quality of the environment. From some literature related to reverse logistics, there are basically four things that considered being the motives of reverse logistics, namely the economic aspects, environmental aspects, legal aspects, and extended responsibility. 
Figure 2 Basic activities and flows in reverse logistics

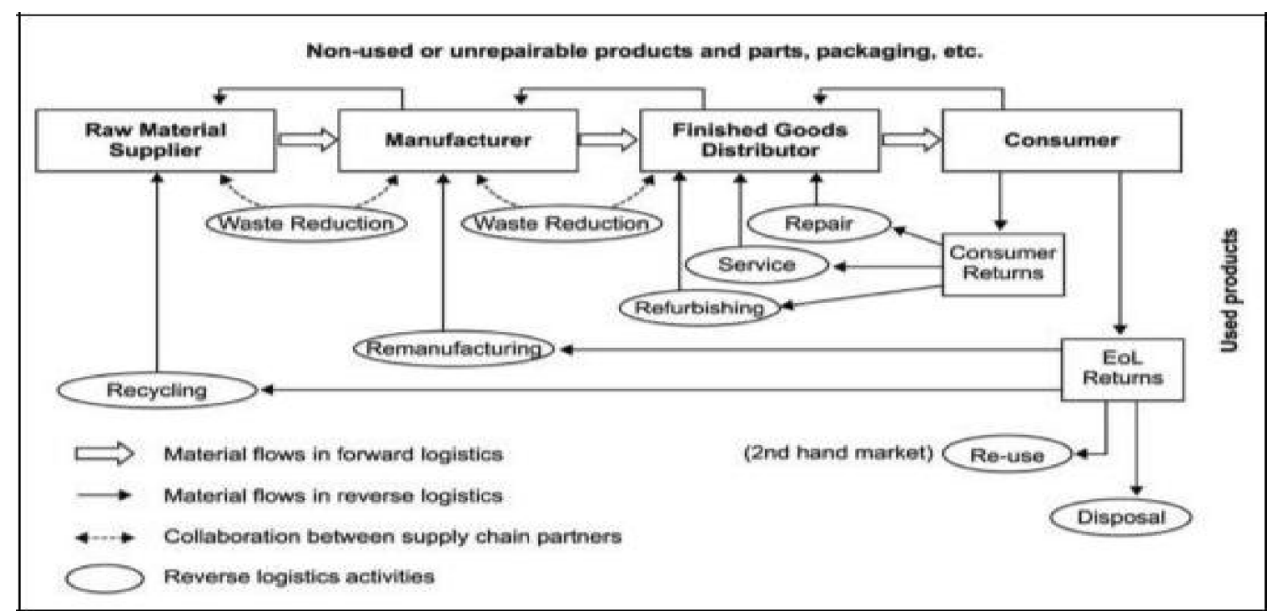

Source: Adapted from Srivastava (2008) in Lau and Wang (2009)

Some explanations about reverse logistics by experts say that reverse logistics is a process that includes logistics activities along the way of products that are not used by the user to be made into a re-product that can be used in the market (Fleischmann et al., 1997). Reverse logistics is the ability of logistics management and activities that include the activities of reducing, regulating, and disposing of harmful or non-hazardous parts. Including reverse distribution, which causes goods and information to run backwards from normal logistics activities in general (Kroon and Vrijens, 1995). Reverse logistics is the collection, transportation, storage and processing of damaged goods (Krikke, 1998). Reverse logistics is a manufacturing process starting from the receipt of goods or parts of consumer goods for the possibility of recycling, recreation, or disposal (Dowlatshahi, 2000). Reverse logistics as a way to repair failed products such as on the packaging and delivery of goods and return the goods to the main point of collection for recycling or repair (Guide et al., 2000).

Basically, there are four things that become the motive of reverse logistics:

- $\quad$ economic aspect, whereby a person or company intends to recover profits from used goods

- environmental aspects, where the person or company reverse logistics to reduce the negative impact of environmental waste products, in addition, reuse of used materials can reduce the exploitation of virgin materials

- $\quad$ legal aspect, usually occurs in developed countries, where the government forces producer companies to perform these activities

- $\quad$ extended responsibility, this motive is done by companies that have their own awareness to do reverse logistics as a form of responsibility to the community and the environment due to the product produced. 
As mentioned before, the process that happens in reverse logistics is essentially similar to the activity that occurs in traditional logistics, but there are some differences, as explained by De Brito et al. (2005) including:

- On the reverse logistics supply, there are many points where the product can be obtained as well as the collection point.

- It takes a good cooperation and voluntary contributions from suppliers of products, in this case, is the consumer, to hand over the goods to the point of collection of the product.

- Items are collected usually have a low economic value. Unlike traditional logistics come first, logistics to reverse logistics network in various aspects need to be developed.

The increasing pressure of various circles on the sustainability of green-production/green company that is happening at the moment, makes the reverse logistics strategy to be one of the main strategies that may be considered by companies to deal with the crisis. Gungor and Gupta (1999) state that the company's attention on the environment can be further improved by regulating the production flow in vain, and the handling of the remainder of unused raw materials. In accordance with the triple bottom line concept that formulates the sustainability and growth of the company depends not only on the operating profit (profit) alone, but also concrete action by the company against the social circumstances (people) and the environment (planet). The three components of the triple bottom line move dynamically depend on the circumstances and the pressure of social, political, economic, environmental, and due to possible conflicts of interest of certain parties (Elkington, 1998). It shows that the concept of social concern for the environment is one of the important concepts that should be applied to support the company's strategy. However, that does not mean that reverse logistics is similar to the green logistics which is fully focused on the environmental aspects. Manufacturing environmentally conscious is a step further than just manufacturing product, that only implementing forward logistics.

\subsection{Green concept and reverse logistics}

The 'green' concept first appeared in the 1970s, when relationships between economic development, the development of the social relationship, environment and natural resources were noticed and defined (Jedlinski, 2014). Environmental management has been widely accepted by the organisation. The firms are adopting practices and processes in the supply chains that pose a lesser threat to the environment (Serrano et al., 2013). Integration of environmental objectives in supply chain management is no longer a secondary aspect. Nowadays companies are going much further to realise that the green supply chain represents major opportunity to generate revenue through reverse logistics activity such as recycling waste to the value-added product. Value-added is the value of a commodity due to the processing, transportation, and storage or in a production. As argued by Hayami et al. (1987) in Hidayat et al. (2012), the value added is the difference between the value of the final product by the 
value of raw materials and other inputs. Generally, reverse logistics is controlled by several factors such as environmental legislation (Nnorom and Osibanjo, 2008); the extension of the responsibility of the manufacturer (Extended Producer Responsibility) (Khetriwal et al., 2009); the economy (Liu et al., 2008); and improved customer service (Wu and Cheng, 2006). So basically the reverse logistics strategy can become a competitive force for the company.

The operation process of a company is not only the final product produced, but also produces waste. Waste can be defined as any work activities that do not provide valueadded in the process of transforming inputs into outputs throughout the value stream (Gaspersz, 2011). Waste can also be defined as a material that is wasted or discarded from the source as the results of human activities and natural processes that do not have economic value (Tchobanoglous et al., 1993). According to Tchobanoglous et al. (1993), solid waste is all scrap arising from human activities that are normally solid and discarded when no longer desired or drained. Waste or scrap of waste is the result of human activity that comes from waste generating activities such as market, households, commercial activities such as shops, restaurants and hotels, as well as other activities such as industrial activities that generate waste.

\section{Research methods}

The approach used in this study is a qualitative approach that is able to provide flexibility and allow researchers to obtain information from primary sources (first-hand information). Zikmund et al. (2013), through a qualitative approach, conduct an elaborated interpretation of information to find the substance of a phenomenon without relying on purely quantitative measurements (numerical measurement), but focused on the discovery of a phenomenon substance and find a new understanding of the perspectives. The research design is using the case study method, which is expected to answer the question 'what/how' in a phenomenon/problem that occurs in an organisation (Yin, 2014). Such design is done with consideration to get a deep idea on the design of reverse logistics on the management of waste generated in the form of coffee grounds to create economic value in the supply chain process. Yin (2014) also mentions that case studies can be categorised into three: explanatory, exploratory, and descriptive. This research will use exploratory case study, because this research aims to explore the design of green reverse logistics on coffee ground waste management. The purpose of this study is to provide a descriptive analysis of the basic methods of the reverse logistics implementation and examine how green reverse logistics initiates a green business opportunity. A case study approach is considered the best method for this purpose. The advantage of this approach is the high level of interaction with the research object, which allows in-depth investigation. The key advantage of this approach is the high level of interaction with the organisations, which allows in-depth investigation (Rowley, 2002). The case study unit of analysis can be considered to be an event, a decision, a program, an implementation process or an organisational change (Rowley, 2002). 


\subsection{Data collection procedures}

The data collection is conducted by direct observation, internal document and literature study, interview with managers and owner who were familiar with the business process and waste of the coffee ground.

- Observation, a preliminary study aimed to see, know and understand the problems and the phenomenon of what is happening in some café/coffee shop in Surabaya. Observation or research directly to several café/coffee shop located in the Surabaya to obtain the real data and see the firsthand process on the spot. Problems and phenomena that occur in the café/coffee shop. By observing the production system and supply chain and reverse logistics systems of the café/coffee shops to see the problem.

- A literature study and internal documents enable the researcher to view and get information about the phenomenon or problem that occurs in some café/coffee shop in Surabaya with the support of existing theories. Obtained from books, journals about the economy and also of the materials that are generally associated with this research as reference material. The criteria of the conceptual framework of reverse logistics and supply chain management are applied to subsequent case analysis to determine the implementation of green business opportunity through the reverse logistic. The conceptual framework is also an important factor in order to develop specific question use in the semi-structured interview protocol.

- Interviews conducted to excavate or search data with the semi-structure interview protocol. The informants or respondents of this research are informants who know and understand about the field, such as café managers, barista, and also the people from the urban farming community in Surabaya city who will become one of the potential markets as a user of the coffee ground green business (fertiliser from coffee grounds product).

- Secondary data from the internet. Data derived from sites containing about things that related to the theme or subject matter of the study.

This research is conducted at cafés/coffee shops which actively operate in Surabaya city. There are 69 outlets with the following details: There are four outlets in North Surabaya, 15 outlets in Central Surabaya, 20 outlets in West Surabaya, 18 outlets in East Surabaya, and 12 outlets in South Surabaya. Analysis of the data used in the qualitative research done by using words that are always arranged in an expanded text or described (Miles and Huberman, 1994). As stated by Moleong (2004), triangulation can be grouped into four types of analytical techniques; the triangulation method, researchers, source, and theory.

\section{Analysis and results}

The research focuses on interviews, surveys and observations conducted on 13 popular and branded café/coffee shop in Surabaya. This selection of the coffee shop is based on 
the location/ layout of the café/coffee shop itself. Selection of the 13 popular cafés/coffee shops is based on the geographical location of the premises which are scattered in various areas in Surabaya. Table 2 shows the informants' profile of 39 outlets of the coffee shops from 13 modern coffee shops in Surabaya which selected as an object of the research. Profile of the informants consists of four positions in the coffee shops, the owner, manager, supervisor and barista. The 39 outlets of coffee shops are selected as research objects to represent $56.5 \%$ of the total number of coffee shops outlets recorded in Surabaya, Indonesia.

Table 2 Profile of informants

\begin{tabular}{lllcl}
\hline No. & Coffee shops name & Geographic Location in Surabaya & $\begin{array}{c}\text { Number } \\
\text { of outlet }\end{array}$ & $\begin{array}{c}\text { Position of } \\
\text { informants }\end{array}$ \\
\hline 1 & Libreria Coffee \& Eatery & East of Surabaya & 1 & Owner \\
2 & Coffee Toffee Specialty & East and South of Surabaya & 3 & Manager \\
3 & Kabinet Coffee & West of Surabaya & 1 & Barista \\
4 & Monopole Coffee \& Pastry & West of Surabaya & 1 & Barista \\
5 & Historica Coffee \& Pastry & Center of Surabaya & 1 & Supervisor \\
6 & Starbucks & Center, West, East, South of Surabaya & 10 & Supervisor \\
7 & J.Co Donuts \& Coffee & Center, West, East, South of Surabaya & 7 & Supervisor \\
8 & Coffee Bean \& Tea Leaf & Center, West, East of Surabaya & 5 & Barista \\
9 & Calibre Coffee roasters & Center of Surabaya & 1 & Barista \\
10 & Rollass Coffee \& Tea & North, Center, South of Surabaya & 3 & Barista \\
11 & De Mandailing & South, East of Surabaya & 2 & Barista \\
12 & My Kopi O & North, West, South of Surabaya & 3 & Barista \\
13 & Oos Koffie \& thee & East of Surabaya & 1 & Barista \\
\hline
\end{tabular}

Another informant needed is from the hydroponic community in Surabaya. The hydroponic community is one of the potential markets for fertiliser of coffee grounds. In this case, the informant is the public relation of Surabaya hydroponic community.

The step and analysis are used to find the model. Those are conducted in three steps:

- Supply chain scheme in coffee shop industry. In this, subsections will explain the scheme early picture of the supply chain that is the forward logistics system, of café/coffee shop industry in Surabaya.

- The potential amount of coffee grounds. This sub-section explains the potential amount of coffee grounds produced by the café/coffee shop industry in Surabaya, with a total of 69 actively operating coffee shop outlets. The potential amount of coffee grounds will be used as a reference for preparing a reverse logistics plan on the management of coffee grounds in the supply chain. In this sub-chapter also explained about the obstacles faced by cafés/coffee shops in managing coffee grounds independently in order to have added value.

- Designing reverse logistics in managing waste. 
In this section will be explained about the design of reverse logistics activities in the process of managing coffee grounds produced by café/coffee shop to be processed into fertiliser/fertiliser plants as described in the previous chapter.

\subsection{Supply chain scheme on the café/coffee shop industries in Surabaya}

Based on the observation in the coffee shop and café, the information in the supply chain process is based on a system of forward logistics of café/coffee shop as shown in Figure 3.

Figure 3 Supply chain scheme on café/coffee shops in Surabaya

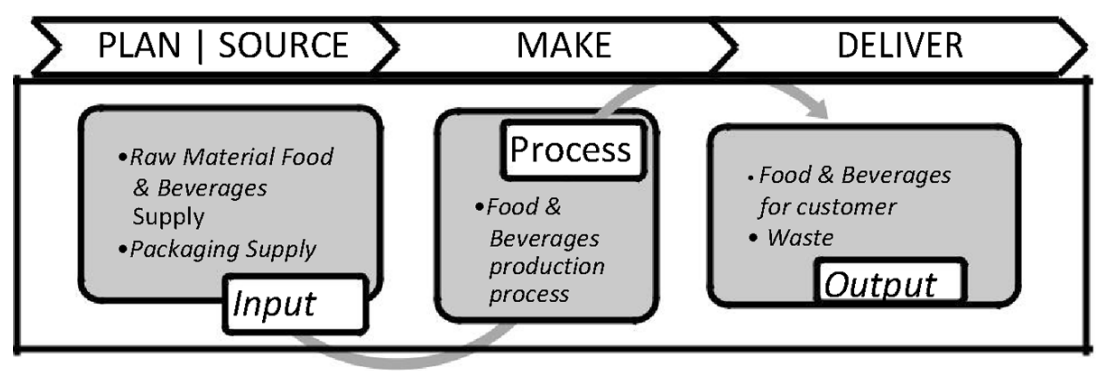

Figure 3 shows that the supply chain process in the café/coffee shop in Surabaya still refers to forward logistics system. As described by Srivastava (2008) in the paper written by Lau and Wang (2009), forward logistics is a supply chain system that focuses on activities such as movement or supply of materials from suppliers, processing of materials in the production, and distribution of the final product to the consumer. The supply chain process at café/coffee shop in Surabaya is divided into three main activities. Firstly, inputs containing the supply/supply activities of suppliers are food and beverages and non-food and beverages such as packaging. In the input phase, there is also an activity plan that includes inventory planning and control processes as well as source activities that include supplier selection activities, evaluating supplier performance, shipping scheduling from suppliers, receiving, checking, and making payments to suppliers. Second, raw material processing activities/materials (food and beverages) are processed into foods and beverages ordered by consumers. In the process of processing the raw materials into products that fit to the customer. Third, delivery activities that include a process to meet the demand for these products in terms of food and beverage customer orders. Besides those activities, the coffee making process also produces waste during the production process. One of the wastes is coffee grounds. Unfortunately, none of the coffee shops in Surabaya is managing their waste.

Based on observations and interviews with several informants from café/coffee shop industry in Surabaya, it is found that the café/coffee shop did not manage their waste. No one makes efforts of the waste to be processed into new products that can provide value added. As the statement disclosed by an informant of Libreria Coffee \& Eatery as follows:

“..... The coffee ground usually just thrown away. Never been processed, because it's also no use anymore we cannot use it to be another drink." 
The information is also underlined by the statement expressed by informants from Starbucks who states the following as below:

“...... so the coffee ground, .... so far we always produce waste every day we just throw away, no one wants the coffee ground because it's not valuable anymore..."

In addition, there is information from interviews with informants of the 'Cabinet Coffee shop' stating that there has been no effort to manage waste coffee grounds to be new products, as disclosed in this following statement:

“...... coffee grounds? thrown away like other cafes. before work in here I've worked in another café, outside the city of Surabaya, the waste of coffee are thrown away as well."

Based on the above facts, it is concluded that café/coffee shop in Surabaya is still adopting forward logistics system, which supply chain activities start from supply process of raw material from the supplier, then the process of supply of food and beverage to the consumer and ending with waste disposal activity of production, no reverse.

\subsection{Potential amount of coffee grounds}

Based on the observation of several café/coffee shop in Surabaya, it can be obtained some information that there is a potential amount of waste in the form of coffee dregs of about $1-2 \mathrm{~kg}$ per a day/outlet. This amount if calculated on the period of 1 month with the assumption of 25 working days, then it can be obtained potential waste coffee grounds about $25-50 \mathrm{~kg} / \mathrm{month} /$ outlet, in order to obtain information that the total amount of potential waste coffee grounds produced by 69 outlets café/coffee shops are still active in Surabaya amounted to $1725-3450 \mathrm{~kg} /$ month. The above statement is supported by a quotation statement obtained from the interview with Informant 2 of Coffee Toffee as follows:

"...... I am working rolling to some places, can be in all branches sometimes in Klampis, yes sometimes in here, sometimes in Rungkut. The most crowded is in Klampis area, because indeed the students' area. If in Jatim Expo, the consumers are literally working people which mostly used for meetings. If there is an event or weekend in East Java Expo, in estimating it can be 1-2 kg, weekend more can $3 \mathrm{~kg}$."

Another informant from the Monopole Coffee Lab also provides information regards to the amount of coffee grounds produced, as revealed by the following interview quotes:

"Mmmm ... coffee grounds? Here more or less.... per day between 1 till $1.5 \mathrm{~kg}$, if really crowded can be 2 to $3 \mathrm{~kg} . . . "$

Information on the potential amount of coffee grounds is then used for reference in making reverse logistics designs on waste management of coffee grounds and can be considered to be a new business opportunity given the abundance of coffee grounds thrown away by the café/ coffee shop in Surabaya every day. Based on the interview to seek further information with informants from Libreria Coffee \& Eatery regarding the constraints faced in managing the waste of coffee grounds, obtained additional information through the following statement quotation: 
“... Because the amount of coffee ground is less (not much). Besides the labor factor, I think if you want to make the product there should be a team of its own, that specifically manage, because it takes time and extra effort to do it and it raises the cost of ...."

The same statements were also given by informants from 'de Mandailing café'. From that statements information about the constraints faced in managing coffee waste, and it can be concluded that there are some obstacles faced by the cafe/coffee shop managers in Surabaya in managing waste independently, namely

- the amount of waste of coffee is limit

- limited time, there is no time to process the coffee grounds

- limited human resources.

These three factors become the main obstacles from the café/coffee shop manager in managing the waste of coffee grounds to be processed into a new product that can create added value and generate additional income. So it is not possible the café will do its own reverse process for coffee grounds, and will remain a waste that will impact on the environment and not be useful. An alternative that can be done to process the coffee grounds is through a third party who wants to run it. Because the business value is not too big, then the most appropriate to do this business is to build start-up entrepreneurs.

\subsection{Plan for waste management in green reverse logistics of coffee grounds}

The amount of potential coffee grounds is thrown away by the café/coffee shop industry in Surabaya is about $1725-3450 \mathrm{~kg} / \mathrm{month}$ as well as the availability of several options in conducting the processing of waste in the form of coffee grounds that are not worth to be a new product. This makes it the basis of research in determining the design of reverse logistics on the management of waste coffee grounds which can be considered as a new business idea. Later on, it will be explained about the proposed design of green reverse logistics activities on the management waste of coffee grounds in order to create economic value in the supply chain process industries café/coffee shops in Surabaya as shown in Figure 4.

Figure 4 shows the proposed design of reverse logistics activities focused on the process of managing waste coffee grounds obtained by collecting coffee grounds that have been discarded by several café/coffee shops conducted by a third-party logistic. The plan of reverse logistics proposal is intended to provide an overview of new green business opportunities for third-party/parties logistic. As mentioned above, there are constraints faced by café/coffee shop managers to manage coffee waste independently, so the proposed reverse logistics design is intended to provide new business opportunities for third parties/parties who willing and able to perform waste management coffee grounds to be processed into a valuable product.

Reverse logistics activities on the waste management of coffee produced by café/coffee shops starting from the process of making coffee grounds from café/coffee shops. Coffee grounds are the main raw material in the input process of green reverse logistics activities. In the input process, there are also other activities, i.e., the supply of goods that become raw material support such as packaging used to pack new products in the form of organic fertiliser. Waste management activities continue to the next stage of the waste processing which is the coffee waste are processed into organic fertiliser. 
At this stage of processing is divided into two main activities, namely the process of drying pulp, processing of coffee, and packaging process. After these steps are done, then the organic fertiliser is ready to be distributed to consumers. The final stage of the supply chain process based on reverse logistics is the output process, wherein the organic fertiliser is packaged together and ready to be distributed to consumers. In the output phase, there are also activities that include the delivery process to meet consumers demand for organic fertiliser products. Furthermore, there is also activity returns if there are defects in the production process.

Figure 4 Plan model for waste management in reverse logistics of coffee grounds



The potential market or primary target users of organic fertiliser products that are made from the coffee grounds are the community of urban farmers. As expressed in previous research that has been done by Adikasari (2012), organic fertiliser based coffee grounds are a nutritional enhancer for plants that can be applied to plants that using hydroponic planting media. But, it does not rule out that the organic fertiliser can also be applied to the other media organic planting, for instance, the process of planting through the media soil as we have known so far.

\subsection{Green business opportunity of coffee ground through reverse logistics in supporting urban farming}

Based on the results of the triangulation process, with the hydroponic community and the result of the previous research, it indicates that coffee grounds is an economic and environmentally friendly fertiliser. Coffee grounds contain $2.28 \%$ nitrogen, $0.06 \%$ phosphorus, and $0.6 \%$ potassium. Slightly, the acidic $\mathrm{pH}$ of coffee grounds is ranging from 6.2 on the $\mathrm{pH}$ scale. In addition, the coffee grounds contain magnesium, sulphur and calcium that are useful for plant growth (Adikasari, 2012). The study uses hydroponic tomato plants through the media as a research object. Hydroponic planting medium is a way of farming without the use of soil media that is currently prevalent in the area of agricultural that has minimum/limited land, especially in urban areas in Indonesia. 
Alongside with the development of science and technology, in urban areas many farms and plantations converted into industrial areas, warehousing, as well as housing. As known, farming is a concrete effort that can be done to prevent global warming. This research also finds the information that the city of Surabaya is a city with a population that has considerable enthusiasm in doing farming activities, or better known as the urban farming trend. Urban farming is one of solutions development of agriculture sector due to limited land is being aggressively promoted by the government through the Department of Agriculture of Surabaya. As revealed by Mr. Djoestamadji, head of food agriculture of Surabaya in papers on www.antarajatim.com in July 2015 edition, urban farming is one solution that can be applied in view of the limited farmland and plantations located in Surabaya.

An example of implementation of urban farming activities using hydroponic media is mostly hydroponic systems are using water main elements and complementary elements in the form of bricks, gravel, or other solid material. One of the pioneers in the development of urban farming in Surabaya is an organisation call Hydroponics Community Surabaya (SHC). In this study, researchers conduct observations and interviews to explore more about the market potential of the organic fertiliser made from coffee grounds and triangulate the source of that performed on the PR Community Hydroponics Surabaya with an informant's name is Mrs. Fananah Firdausi located in Green House Puspa Agro, Jalan Sawunggaling 177-183, Jemundo (Kletek), Taman, Sidoarjo, East Java, Indonesia. Based on observations and interviews, it is said that the plants grown using the medium of hydroponics have the advantage of ease of cultivation methods, cheapening the costs involved, and the resulting product is healthier for the body because the plants are grown with media hydroponic free of pesticides, fungicides, and insecticides.

Currently, Community Hydroponics Surabaya has a membership of some 19,000 people and has business potential from the vegetable market that is much in demand at home and abroad. This is consistent with the statement of the Chairman of Farmers' Cooperative Hydroponics East Java, Mr. Yoso Susrianto in an article published in the daily Surya Online edition of March 2015 stating that there is a potential demand of up to 1 tonne of vegetables every month to be able to meet demand needs in vegetables both at home and abroad. To perform the calculation of economic value that can be obtained through reverse logistics activities on the management of waste coffee grounds, researchers refer to research conducted by Hidayat et al. (2012). These studies use Hayami method adapted and developed in accordance with the characteristics of the agro-industrial supply chain of palm oil, and eliminate the weaknesses that exist in the method. A modification made is the basis for calculating using the value of money, no more weight materials and products.

\section{Conclusion}

Based on the analysis data from various resources whose managing of the café/coffee shop in Surabaya, literature review on the concept of reverse logistics on the management of waste coffee grounds, as well as the results of triangulation can be concluded that in general, the supply chain process in the café/coffee shop in Surabaya still refers to a forward logistics system that focuses on activities such as: the supply of raw materials by 
suppliers to the process of providing food and beverages to final consumers and stops the waste disposal activities remainder of production.

Café/coffee shop businesses in Surabaya do not make an effort to manage waste of coffee grounds to be processed into new products that can provide economic value. Obstacles faced by the café/coffee shop in managing their waste independently is the limited amount of coffee grounds waste generated for each cafe, limited of time and human resources that willing to conduct utilisation of waste coffee grounds. Through the concept of reverse logistics, waste coffee grounds of the café/coffee shop can be utilised as an organic fertiliser that is economical and environmentally friendly, and can act as an enhancer of nutrients for plant growth.

This study provides an overview of the new business opportunities in relation to the management of waste coffee grounds to make a profit by creating a new product that is the organic fertiliser that has more value, as well as supporting the concept of the triple bottom line of a business. This research is only done until the design phase reverse logistics, so it is advisable to be able to proceed with further research, by expanding the scope of the study so that the results can be generalised to create green reverse logistics implementation. The practical implications for small entrepreneurs or start-up business should be more creative and innovative in creating new business opportunities, especially on the management of waste.

\section{References}

Adikasari. R. (2012) Utilization of Tea Shampoo and Coffee Cut as Addition of Nutrition at Tomato Plant Growth (Solanum lycopersium) with Hydroponics Media, Universitas Muhammadiyah Surakarta.

Daugherty, P.J., Richey, R.G., Genchev, S.E. and Chen, H. (2005) 'Reverse logistics: superior performance through focused resource commitments to information technology', Transportation Research, Part E, Vol. 41, pp.77-92.

De Brito, M.P., Dekker, R. and Flapper, S.D.P. (2005) 'Reverse logistics: a review of case studies', Distribution Logistics, Springer, Berlin, Heidelberg, pp.243-281.

Dowlatshahi, S. (2000) 'Developing a theory of reverse logistics', Interfaces, Vol. 30, No. 3, pp.143-155.

Elkington, J. (1998) Cannibals with Forks: The Triple Bottom Line in 21st Century Business, New Society Publishers, Gabriola Island, BC.

Fleischmann, M., Jacqueline, M., Van der Laan, E., Van Nunen Jo, A.E.E. and Van Wassenhove, L.N. (1997) 'Quantitative models for reverse logistics: a review', European Journal of Operational Research, Vol. 103, pp.1-17.

Gaspersz, V. (2011) The Executive Guide to Implementing Six Sigma, PT Gramedia Pustaka Utama, Jakarta.

Georgiadis. P. and Vlachos. D. (2004) 'Decision making in reverse logistics using system dynamics', Yugoslav Journal of Operation Research, Vol. 14, No. 2, pp.259-272.

Guide Jr., V.D.R., Jayaraman, V., Srivastava, R. and Benton, W.C. (2000) 'Supply-chain management for recoverable manufacturing systems', Interfaces, Vol. 30, pp.125-142.

Gungor, A. and Gupta, S.M. (1999) 'Issues in environmentally conscious manufacturing and product recovery: a survey’, Computers \& Industrial Engineering, Vol. 36, pp.811-853.

Hayami, Y., Kawagoe, T., Morooka, Y. and Siregar, M. (1987) Agricultural Marketing and Processing in Upland Java. A Perspective from a Sunda Village, The CPGRT Centre, Bogor.

Hidayat, S., Marimin., S.A., Sukardi and Yani, M. (2012) 'Modification of Hayami's value added method for the palm oil', Jurnal Teknologi Industri Pertanian, Vol. 22, No. 1, pp.22-31. 
Jayaraman, V., Patterson, R.A. and Rolland, E. (2003) 'The design of reverse distribution networks: models and solution procedures', European Journal of Operational Research, Vol. 150, pp.128-149.

Jedlinski M. (2014) 'The position of green logistics in sustainable development of smart green city', 1st International Conference Green Cities 2014-Green Logistic for Green Cities, Elsevier Ltd.

Khetriwal, D.S., Kraeuchi, P. and Widmer, R. (2009) 'Producer responsibility for e-waste management: key issues for consideration-learning from the Swiss experience', Journal of Environmental Management, Vol. 90, No. 1, pp.153-165.

Krikke, H. (1998) Recovery Strategies and Reverse Logistic Network Design. Institute for Business Engineering and Technology Application, PhD Thesis, Enschede, the Netherlands, University of Twente, p.254.

Kroon, L. and Vrijens, G. (1995) 'Returnable containers: an example of reverse logistics', Omega, Vol. 30, pp.325-333.

Lau, K.H. and Wang, Y. (2009) 'Reverse logistic in the electronic industry of China: a case study', An International Journal, Vol. 14, No. 6, pp.447-465.

Liu, X., Tanaka, M. and Matsui, Y. (2008) 'Economic evaluation of optional recycling processes for waste electronic home appliances', Journal of Cleaner Production, Vol. 17, No. 1, pp.53-60.

Miles, M.B. and Huberman, A.M. (1994) Qualitative Data Analysis: An Expanded Sourcebook, Sage.

Moleong (2004) Qualitative Research Method.

Muflichah, N. (2014) Reverse Logistic Model Implementation in Cigarette Industry in Sidoarjo, Indonesia, Working Paper.

Ninlawan, C., Seksan, P., Tosappol, K. and Pilada, W. (2010) 'The implementation of green supply chain management practices in electronics industry', Proceedings of the International Multi Conference of Engineers and Computer Scientists, Hong Kong.

Nnorom, I.C. and Osibanjo, O. (2008) 'Overview of electronic waste (e-waste) management practices and legislations, and their poor applications in the developing countries', Conservation and Recycling, Vol. 52, pp.843-858.

Pauli, G. (2010) The Blue Economy, 10 Years, 100 Innovations, 100 Million Jobs, Paradigm Publication.

Rogers, D.S. and Tibben-Lembke, R. (1999) Going Backwards: Reverse Logistics Trends and Practices, Reverse Logistics Executive Council, University of Nevada, Reno Center for Logistics Management.

Rowley, J. (2002) 'Using case studies in research', Management Research News, Vol. 25, No. 1, pp.16-27.

Serrano, C., Aggoune-Mtalaa, W. and Sauer, N. (2013) 'Dynamic models for green logistic networks design', IFAC Proceedings, Vol. 46, No. 9, pp.736-741.

Srivastava, S.K. (2008) 'Network design for reverse logistics', Omega: The International Journal of Management Science, Vol. 36, No. 4, pp.535-548.

Tchobanoglous, G.T., Theisen, H. and Vigil, S.A. (1993) Integrated Solid Waste Management Engineering Principles and Management Issues, McGraw Hill, New York, NY.

Yin, R.K. (2014) Case Study Research: Design and Methods, 5th ed., Sage Publications Inc., New York.

\section{Websites}

Coffee \& Tea in Surabaya, https://www.tripadvisor.com/Restaurants-g297715-zfg9900 Surabaya_East_Java_Java.html (downloaded at 31 March, 2016). 
Consumption of Indonesia Coffee, http://www.aekiaice.org/uloads/download (19 January, 2016).

Triple Bottom Line: Lebih Dari Sekedar Profit, http://swa.co.id/my-article/triple-bottom-line-lebihdari-sekadar-profit diunduh tanggal (24 February, 2016).

Urban Farming, Solusi Keterbatasan Lahan di Surabaya, http://www.antarajatim.com/ lihat/berita/160736/urban-farming-solusi-keterbatasan-lahan-di-surabaya diunduh tanggal (20 Mei, 2016).

\section{Bibliography}

Bolstorff, P. and Rosenbaum, R.G. (2012) Supply Chain Excellence: A Handbook for Dramatic Improvement using the SCOR Model, 3rd ed., American Management Association, New York, NY.

Brown, A.C. (2008) Understanding Food Principles and Preparation, 3rd ed., Thomson Wadsworth.

Canel, C., Rosen, D. and Anderson, E.A. (2000) 'Just-in-time is not just for manufacturing: a service perspective', Industrial Management \& Data Systems, pp.51-60.

Chalker-Scott, L. (2009) Coffee Grounds - Will They Perk Up Plants?, Washington State University.

De Brito, M.P., Flapper, S.D.P. and Dekker, R. (2002) 'Reverse logistics: a review of case studies', Econometric Institute Report EI, Vol. 21, pp.1-31.

Dischinger, J., Closs, D.J., Grenoble, W. and Marshall, D. (2006) 'The emerging supply chain management profession', Supply Chain Management Review, Vol. 10, No. 1.

Green Jr., K.W., Whitten, D. and Inman, R.A. (2008) 'The impact of logistics performance on organizational performance in a supply chain context', Supply Chain Management: An International Journal, Vol. 13, No. 4, pp.317-327.

Ming-Chih, T., Chun-Hua, L. and Chia-Shing, H. (2008) 'Risk perception on logistics outsourcing of retail chains: model development and empirical verification in Taiwan', Supply Chain Management: An International Journal, Vol. 13, No. 6, pp.415-424.

Pujawan, N. (2010) Supply Chain Management, 2nd ed., Guna Widya, Surabaya.

Richey, R.G., Genchev, S.E. and Daugherty, P.J. (2005) 'The role of resource commitment and innovation in reverse logistics performance', International Journal of Physical Distribution and Logistics Management, Vol. 35, No. 4, pp.233-257.

Simchi-Levi, D., Kaminsky, P. and Simchi-Levi, E. (2009) Designing \& Managing the Supply Chain, 3rd ed., McGraw Hill, New York, NY.

Sugiyono (2007) Qualitative and Quantitative Educational Research Method, Pendekatan and R\&D, CV.Afabeta, Bandung.

Teggia, G. and Hanusz, M. (2003) A Cup of Java, Equinox Publishing (Asia) Pte. Ltd, First Equinox.

Wu, Y-C.J. and Cheng, W-P. (2006) 'Reverse logistics in the publishing industry: China, Hong Kong, and Taiwan', International Journal of Physical Distribution \& Logistics Management, Vol. 36, No. 7, pp.507-523.

Zhu, Q., Sarkis, J. and Lai, K. (2005) 'Green supply chain management implications for 'closing the loop", Transportation Research Part E, Vol. 44, No. 1, pp.1-18.

Zikmund, W.G., Babin, B.J., Carr, J.C. and Griffin, M. (2013) Business Research Methods, 9th International Edition, Cengage Learning, Canada. 